특집논문-11-16-3-01

$$
\begin{gathered}
\text { 방송콘텐츠 유통서비스를 위한 실시간 콘텐츠식별자 은닉삽입 시스템 } \\
\text { 김 연 희 }{ }^{a} \text {, 김 현 }^{\mathrm{b})} \text {, 이 주 영 }{ }^{\mathrm{a}} \text {, 남 제 호 }
\end{gathered}
$$

\title{
UCI Embedder: A Real-time Broadcast-Content-Identifier Watermarking System for Broadcast Content Distribution Services
}

\author{
Younhee $\mathrm{Kim}^{\mathrm{a})^{\ddagger}}$, Hyuntae $\mathrm{Kim}^{\mathrm{b})}$, Jooyoung Lee ${ }^{\mathrm{a})}$, and Jeho Nam ${ }^{\mathrm{a})}$ \\ 요 약
}

국가표준콘텐츠식별체계인 UCI를 이용하여 방송콘텐츠를 식별 관리하면 다양한 형태의 콘텐츠가 개방형 시장에서 거래되는 미래 콘텐츠 유통시장에 대응하여 효과적으로 콘텐츠를 관리 할 수 있다. 방송콘텐츠 유통과정의 특성상 여러 가지 형태의 변형이 콘텐츠에 가해지게 되는데, 변형 콘텐츠도 변형 전에 부여된 식별자로 콘텐츠를 식별할 수 있어야 효과적인 콘텐츠 식별 및 관리가 가능하다. 이에 본 논문에서는 워터마킹 기술을 이용하여 UCI 식별자를 방송콘텐츠에 실시간으로 은닉삽입하는 시스템을 제안한다. 방송콘텐츠 를 송출하는 단계에서 UCI 식별자를 은닉삽입하여 콘텐츠 유통의 전 과정을 통해 하나의 식별자로 식별할 수 있도록 고안하였다. 워 터마크 삽입과정으로 인한 화질 저하를 최소화하면서도 변형된 콘텐츠에서도 워터마크를 추출할 수 있는 강인성을 요구하는 방송용 워터마크 삽입 시스템으로 기존의 방송시스템과의 연동을 고려하여 HD-SDI 신호 입출력을 지원하도록 설계 구현되었다.

\begin{abstract}
We introduce the standard content identifier Universal Content Identifier (UCI) and a watermarking system that embeds UCI for the broadcast content distribution services. Our proposed UCI embedder is designed in consideration of integrating with the previously established broadcast system and protecting the illegal distribution of broadcast contents. Our goal is that when broadcast content is transmitted, 28 byte UCI is embedded imperceptibly in the content itself in real-time and the embedded UCI is successfully extracted not only in the typical format used in the broadcast content distribution service but also in the illegally distributed broadcast contents. Usually the illegally distributed contents are modified from the original by changing resolutions, frame rates, or adjusting colors. In this paper, we present a watermarking scheme that embeds 28 byte UCI in broadcast content in real-time while keeping the visual quality high and the embedded watermark robust enough to survive through the various modification. The experimental results show that the embedded UCI remains in the various modified versions of content and that the visual degradation by embedding is not noticeable.
\end{abstract}

Keyword : Content Identifier, Watermarking, Broadcast Content Protection, Real-time Watermarking

a) 한국전자통신연구원 방통융합미디어연구부

Electronics and Telecommunications Research Institute, Broadcasting

\& Telecommunications Media Research Department

b) $C K \& B$ 기술연구소

CK\&B Co., Ltd. Research Institute

\# 교신저자 : 김연희(kimyounhee@etri.re.kr)

※ The authors appreciate the help of the research engineers of SBS

Institute of Technology during the work on the paper.

· 접수일(2011년3월16일), 수정일(2011년5월16일), 게재확정일(2011년5월16일)

\section{INTRODUCTION}

Traffic of digital broadcast contents has grown exponentially in the digital revolution age and broadcasters starts to pay attention in the online content market. 
However, it is very easy to record the digital broadcast contents with the high quality and distribute them on line without permission. Digital watermarking is a powerful technique to protect the copyrights and control access.

We employ a Universal Content Identifier (UCI) standard for an identifier, which was established as a standard in 2008 [9]. UCI is a standard that assigns a unique identifier to digital resource and manages the resources more effectively. UCI is carefully designed to be compatible with the previous content identifier standards such as DOI and ISBN. The advantages by applying UCI to broadcast contents are the following:

- A UCI syntax allows to keep the previously assigned identifier by a content provider or other content identifier standard.

- A UCI syntax allows managing the different versions of the same content. For example, the content transmitted through terrestrial TV may have the different UCI from the content transmitted through cable TV, even if the content is the same program.

- UCI allows easy access to the relevant content through its resolution servers. For example, a user clicks the UCI or an object containing the content's UCI on the Web, the related information including meta-data of the content's title, associated URL, or related content can be provided [10].

Although terrestrial broadcasters assign UCI to their contents, the content is difficult to be identified using UCI once the content is transmitted or recorded after transmission. In order to identify the content using UCI, a UCI identifier is embedded imperceptibly using a watermarking technology in the content itself. Once UCI is embedded in the content, it remains in any format of file and even in the modified version of content. The remained content identifier is very applicable for copyright protection [11] and content management, especially in the on-line content market.
This paper is organized as follows. In Section 2, three requirements to consider embedding a UCI in broadcast content are presented. In Section 3 the detailed UCI watermarking scheme is presented and its implementation is described in Section 4. Experiments and the results are presented in Section 5 and conclusion follows in Section 6.

\section{II. requirements for broadcast content identifier watermarking system}

The following feasibility, speed, and robustness are three important requirements to consider in designing a broadcast content watermarking system, and these three requirements are strongly related to the watermark length. According to the UCI specification, a maximum size for UCI is 512 bytes, but around 20 bytes are the typical length being used for broadcast contents. Thus, we have decided the maximum size of the watermark payload as 28 bytes in the proposed UCI embedder.

\section{- Feasibility}

The video and audio quality is very important for broadcast contents. A watermarking technology adds noise-like watermark signals to the original. Therefore, the watermarked contents cannot have the same objective quality to the original. The proposed UCI embedder is carefully designed to reduce the perceptible degradation by considering the human visual characteristics.

\section{- Speed}

The amount of audio and video data for full HDTV is large--transmitting in a rate of 30 frames per second in the resolution of $1920 \times 1080$. The presented UCI embedder is designed to embed 28 byte UCI into the full HD content in real-time which is a very important requirement for broadcast content providers.

\section{- Robustness}

The goal of embedding a UCI for the application of the 
broadcast content distribution services is that to obtain the UCI from the distributed broadcast content and the modified version of the content for identification. Robustness against the following typical modifications for broadcast contents is one of the important requirements for a UCI embedder.

Format conversion: Since the file formats of distributed broadcast contents are vary, UCI should remain in the contents after format change. Users can easily re-encode the broadcast content using a software tool. Broadcasters encode their content into the required formats for various services such as IPTV or Cable re-transmission.

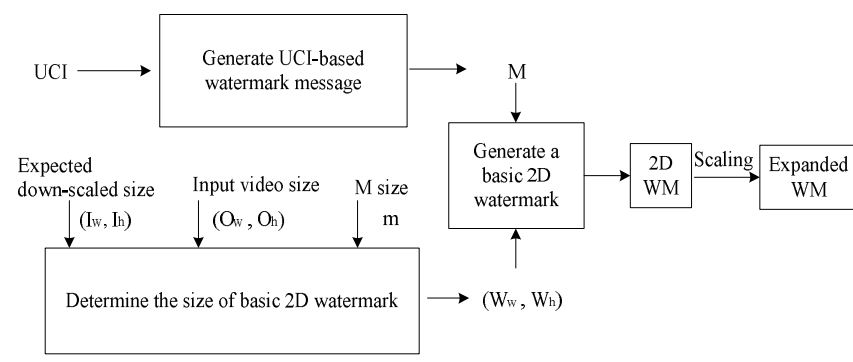

그림 1. $2 \mathrm{D}$ 워터마크 패턴 생성 과정

Fig. 1. Generation of the basic $2 \mathrm{D}$ watermark pattern

Resolution change: Users can easily resize the broadcast content using a software tool. Broadcasters also may resize the broadcast content being suitable for each service: for example, $960 \times 540$ for the high quality VOD service and $400 \times 300$ for the low quality VOD service.

Content Editing: Broadcasters usually overlay their logo, some graphics and captions on the original contents. The embedded UCI is required to remain after the image processing modification.

\section{The proposed UCI watermarking scheme}

In this section, we introduce our watermarking scheme.
Since our embedding system embeds 28 byte UCI in every frame, how to generate the watermark pattern is critical. Many watermarking systems that provide robustness against geometric attacks have been proposed, but our system provides large payload capacity and watermark recovery after the large amount of downscaling attack, as well as real-time embedding. We carefully design the watermark generating scheme in order to remain the watermark (UCI) in the $4 \%$ downscaled $(1 / 25$ in size) content at smallest. The steps of our embedding scheme against downscaling attack are that (a) the size of a basic 2D watermark pattern is determined according to the minimum size of the attacked video, (b) the basic 2D watermark is generated and scaled to the host content size, and (c) the scaled watermark is embedded. The steps of our extracting scheme are that (a) the type of modification of the content is estimated and (b) the watermark is estimated.

\section{Watermark generation}

Let the size of UCI information a in bytes, the size of sync information $\mathbf{b}$ in bytes, and the size of error-correcting information $\mathbf{c}$ in bytes. UCI, sync and error-correcting information are collectively named $\mathbf{W}$ and let its size $\mathbf{m}$ (i.e. $m=a+b+c)$. In the proposed watermarking system, a Spread Spectrum technique [12] is used, which means that a payload bit is represented by a bit stream. In this paper, a basic $2 \mathrm{D}$ watermark pattern refers to the bit stream. How to create the $2 \mathrm{D}$ watermark pattern is crucial in a watermark extraction performance. The proposed method demonstrates a way to design a 2D watermark pattern according to the minimum resolution of the downscaled video.

Let the minimum resolution of the downscaled video is $I_{w} \times I_{h}$. The $I_{w} \times I_{h}$ varies. Obviously smaller resolution of $I_{w} \times I_{h}$ is desired for more robust watermarking system, however in order to make the watermark available in the 
smaller resolution video, the higher level of distortion is evitable, and thus the embedded watermark may be visible. Full HD broadcasting video of $1920 \times 1080$ in pixel size is re-encoded into various resolutions depending on the service. For example, for the high quality in a VOD service, $1280 \times 720$ resolution video is provided; $640 \times 480$ for the middle quality; $400 \times 300$ for the low quality [13]. The proposed watermark embedding scheme repeats embedding the basic watermark pattern for providing robustness against cropping and the aspect ratio change. The size of the basic $2 \mathrm{D}$ watermark is determined in consideration of the number of embedding repetition and the length of the watermark. Once the size of the basic 2D watermark is determined, a watermark sequence having a mean of 0 and a variance of 1 is generated. It is also designed that the correlation of the same watermark will be 1 and the one of the different watermark will be 0 . The block diagram of the proposed watermark generation algorithm is illustrated in Fig. 1.

Since the downscaling process causes a data loss, in order to make the embedded UCI robust against the downscaling attack, we scale the 2D watermark pattern up. The scaled watermark is denoted EW:

$$
E W=\{E W \in\{1,-1\}\} .
$$

There is one problem in scaling up the basic watermark pattern. Embedding the scaled basic watermark may cause visible blocking artifact in especially the smooth region such as the sky region. We have applied a heuristic imperceptible embedding technique using human visual characteristics and modified $E W$ to $E W^{\prime}$ in order to enhance the visual quality.

\section{2. $\mathrm{UCl}$ watermark embedding}

The overview of our UCI embedding and extracting system are illustrated in Fig. 2 and Fig. 3, respectively. Since our system is designed to be easily intergraded in the estab- lished broadcasting environment, the input video is in the format of HD-SDI or SDI signal, which has $\mathrm{Y}, \mathrm{Cb}$, and $\mathrm{Cr}$ color space. A UCI watermark is embedded in $\mathrm{Y}$ (luminance) signal, which is known for more robust against the various modifications than embedding in the chroma space. Let the input frame be I and its total pixel size ben. First, the watermark pattern denoted $E W$ is generated by the proposed algorithm described in the previous section:

$$
E W^{\prime}=\left\{E W_{t}^{\prime} \in\{1,-1\} \mid 1 \leq t \leq n\right\} .
$$

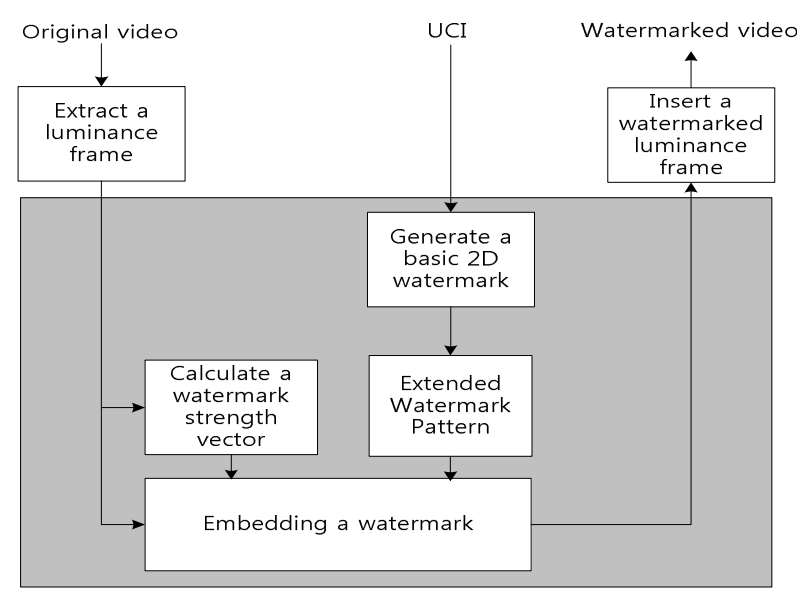

그림 2. $\mathrm{UCl}$ 워터마크 삽입 시스템 구성도

Fig. 2. An overview of the $\mathrm{UCl}$ watermark embedding system.

Our watermark embedding system embeds a UCI watermark as shown in Eq. (1). The watermark strength $\alpha(i, j)$ is calculated on the basis of the utilization of the characteristics of a human visual system (HVS) which is that the noise is easily visible in flat areas than in areas of including edges and textures. The design of obtaining the watermark strength affects the real-time performance of the watermark embedding system because its computation complexity is usually high. The embedding procedure embeds the scaled watermark signal by modifying the original luminance frame based on the watermark strength:

$$
\hat{I}(i, j)=I(i, j)+\alpha(i, j) E W^{\prime}(i, j) .
$$




\section{UCl watermark extracting}

The watermark extracting system extracts a UCI watermark from the watermarked video. Since our watermarking system is designed to prevent the illegal distribution of broadcast content, the embedded UCI in the original still should be extracted from the modified version of the video: format conversion, resolution change, or content editing.

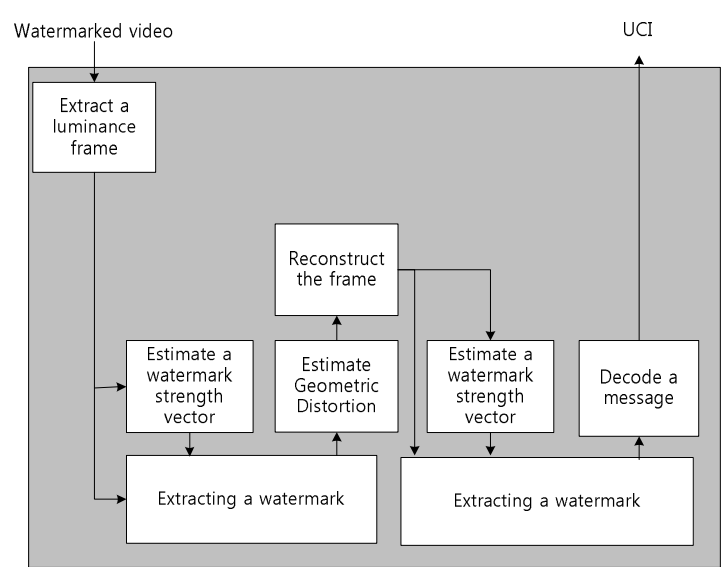

그림 3. $\mathrm{UCl}$ 워터마크 추출 시스템 구성도

Fig. 3. An overview of the $\mathrm{UCl}$ watermark extracting system.

Our UCI watermark extraction proceeds with two steps: estimating of the geometric distortion and detecting a watermark. First, we extract luminance data from the input video frame and then estimate the geometric distortion of the video as proposed in [14]. The original video frame is estimated by applying a denoising filter to the input video frame. The watermark is estimated by subtracting the estimated original video from the input video frame. The ratio of the modified video to the original is calculated based on the periodicity of the watermark signal in the extraction process. The geometric distortion is calculated using the estimated watermark from the first step. Second, the video is reconstructed using the found geometric modification parameters and then a watermark is estimated again from the reconstructed frame. The procedure of extracting the water- mark is the same as the previous step: estimating the original content by denoising, estimating the watermark strength, estimating the watermark. UCI is decoded from the extracted watermark.

\section{Embedder/Detector}

\section{UCl embedder}

Our UCI embedder is carefully designed to provide the heuristic user interface to control the system as shown in Fig. 4. The system is controlled by the menu buttons and the video stream is shown through the installed LCD monitor. To be used in the broadcasting system industry, real-time embedding is required. The commercial video capture cards [15] are installed in our system, providing the interfaces of HD-SDI input and output. The system has multi-core processors, and our embedding implementation uses OpenMP parallel programming to achieve a real-time embedding. The calculation of the watermark strength takes long time, so full-HD frame is divided into 8 sections and each section is processed by utilizing the multi-core system. The boundaries between the sections are processed separately after finishing all 8 sections. Our system embeds UCI of 28bytes in each full HD frame in the rate of 30

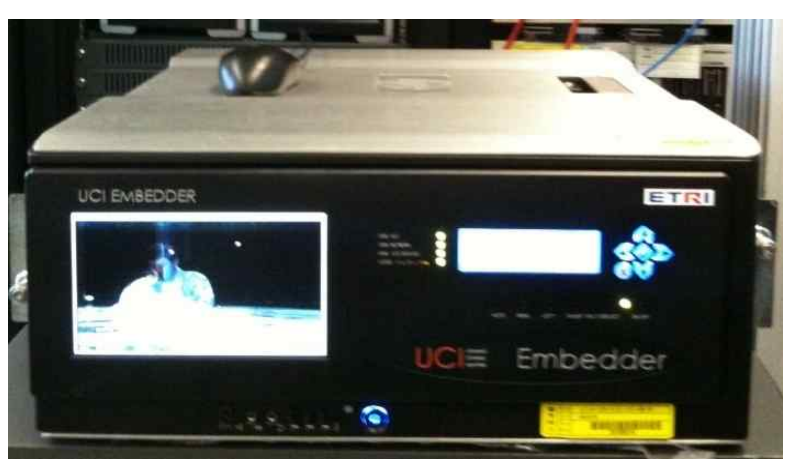

그림 4. 개발한 $\mathrm{UCI}$ 워터마크 삽입기

Fig. 4. Our UCl watermark embedder. 
frames per second.

\section{2. $\mathrm{UCI}$ detector}

Our UCI watermark detector software is shown in Fig. 5. To speed up the watermark extraction process, the geometric distortion ratio and watermark strength are calculated for the first frame and updated after few minutes for the distortion ratio and after few seconds for the watermark strength. For error resilience, we employ two techniques. The watermark detection is determined by summing the estimated watermarks of the 30 consecutive frames and the Reed-Solomon error correction scheme is applied. The input of the detector is the watermarked video. The information of the video format, resolution, and sample rate

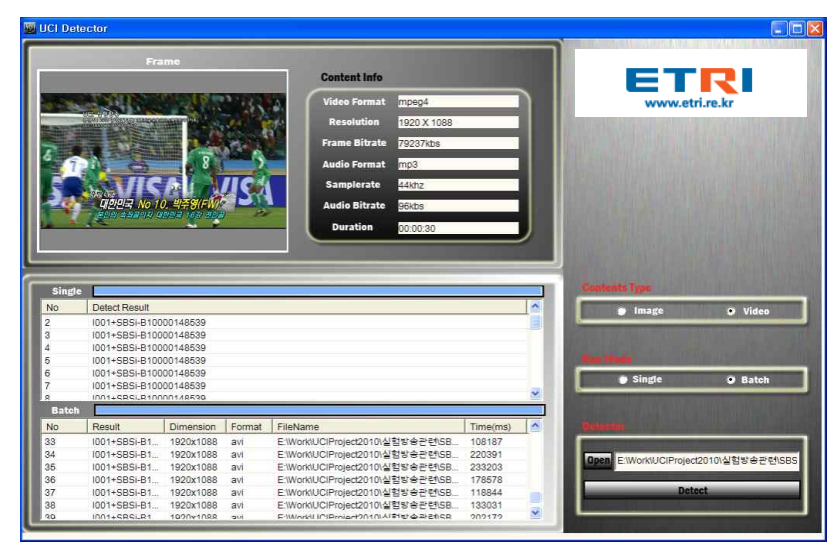

그림 5. 개발한 UCI 워터마크 추출 프로그램

Fig. 5. Our UCl detector software. are displayed. The format, resolution, and sample rate may or may not be the same to the original. The detection result is displayed in every 1 second, which is the result of the 30 frame averaging.

\section{Experiments}

We have integrated our UCI embedder between the video player and the MPEG-2 encoder at a national Korean television network SBS (Seoul Broadcasting System) and have transmitted the watermarked TS for a broadcasting test. The test sequence was prepared taking from the five different broadcast contents as shown in Table 1. The test video was in $1920 \times 1080$ resolutions and runs $1500 \mathrm{sec}-$ onds with 45,000 frames. We have embedded 28 byte UCI in each frame. We have tested the robustness of our UCI embedder by extracting UCI in the modified version.

We have tested the robustness against the various attack of our UCI embedder including re-encoding, caption and graphic insertion, and downscaling, testing if the embedded UCI using our UCI embedder is still extracted after the various combined attacks. The results is shown in Table 2 . The combined attack means that more than one kind of attack have applied to the already attacked content. For example, the subtitle insertion attack and the H.264 recompression attack have been applied to the Mpeg-2 compressed content, which is the first test in Table 2.

\section{표 1. 실험영상}

Table 1. Test sequence.

\begin{tabular}{|c|c|c|c|c|c|}
\hline & Content \#1 & Content \#2 & Content \#3 & Content \#4 & Content \#5 \\
\hline \multirow{2}{*}{ Snapshot } & & & & \\
& & & &
\end{tabular}


표 2. 복합공격에 대한 추출 실험 결과

Table 2. Detection from the combined attacked video

\begin{tabular}{|c|c|c|c|c|c|}
\hline \multirow{2}{*}{ Combined Attack } & \multicolumn{5}{|c|}{ Content No. (detection) } \\
\hline & \#1 & \#2 & \#3 & \#4 & \#5 \\
\hline $\begin{array}{c}1920 \times 1080 \text {, subtitle insertion, H.264 } \\
\text { re-encoding }\end{array}$ & $\mathrm{O}$ & $\mathrm{O}$ & $\mathrm{O}$ & $\mathrm{O}$ & $\mathrm{O}$ \\
\hline $\begin{array}{c}1920 \times 1080, \text { logo insertion, H.264 } \\
\text { re-encoding }\end{array}$ & $\mathrm{O}$ & $\mathrm{O}$ & $\mathrm{O}$ & $\mathrm{O}$ & 0 \\
\hline $\begin{array}{l}1920 \times 1080, \text { median filtering, } \\
\text { grayscale conversion, H.264 } \\
\text { re-encoding }\end{array}$ & $\mathrm{O}$ & $\mathrm{O}$ & $\mathrm{O}$ & $\mathrm{O}$ & $\mathrm{O}$ \\
\hline 1920 x 1080, Divx re-encoding & $\mathrm{O}$ & $\mathrm{O}$ & $\mathrm{O}$ & $\mathrm{O}$ & $\mathrm{O}$ \\
\hline $\begin{array}{c}\text { 1280x720, subtitle, logo insertion, } \\
\text { H.264 re-encoding }\end{array}$ & $\mathrm{O}$ & $\mathrm{O}$ & $\mathrm{O}$ & $\mathrm{O}$ & $\mathrm{O}$ \\
\hline $\begin{array}{c}\text { 960x540, subtitle, logo insertion, } \\
\text { H.264 re-encoding }\end{array}$ & $\mathrm{O}$ & $\mathrm{O}$ & $\mathrm{O}$ & $\mathrm{O}$ & $\mathrm{O}$ \\
\hline $\begin{array}{c}\text { 640x480, subtitle, logo insertion, } \\
\text { H.264 re-encoding }\end{array}$ & 0 & 0 & 0 & $\mathrm{O}$ & $\mathrm{O}$ \\
\hline
\end{tabular}

The aspect ratio change is found frequently in HD broadcast content. $1920 \times 1080$ is the $16: 9$ ratio contents; however, the many media devices have a $4: 3$ ratio displayer. Table 3 shows the results of the detection rate from the downscaling contents. The extraction rate is a ratio of the number of successfully UCI extracted frame over the total number of frames. Recall that the original content is

\section{표 3. 다양한 형태의 화면비 변경에 따른 추출 실험 결과}

Table 3. Detection rates from the aspect ratio modification contents $(\%)$

\begin{tabular}{|c|c|c|c|c|c|}
\hline $\begin{array}{c}\text { Test } \\
\text { No. }\end{array}$ & Resolution & $\begin{array}{c}\text { Aspect ratio } \\
\text { modification type }\end{array}$ & 4 Mbps & 2 Mbps & 1 Mbps \\
\hline 1 & $1280 \times 720$ & $\mathrm{M} 1$ & 100 & 100 & 93.3 \\
\hline 2 & $960 \times 540$ & $\mathrm{M} 1$ & 100 & 100 & 99.3 \\
\hline 3 & & $\mathrm{M} 1$ & 100 & 100 & 92.3 \\
\hline 4 & \multirow{4}{*}{$800 \times 600$} & $\mathrm{M} 1+\mathrm{M} 2$ & 100 & 100 & 92.3 \\
\cline { 1 - 4 } & & $\mathrm{M} 1+\mathrm{M} 3$ & 100 & 100 & 88.7 \\
\hline & & $\mathrm{M} 1+\mathrm{M} 2+\mathrm{M} 3$ & 100 & 100 & 92.3 \\
\hline 5 & $\mathrm{M} 1$ & - & 100 & 98.7 \\
\hline 7 & \multirow{4}{*}{$480 \times 360$} & $\mathrm{M} 1+\mathrm{M} 2$ & - & 100 & 96.1 \\
\hline & & $\mathrm{M} 1+\mathrm{M} 3$ & - & 100 & 90.2 \\
\hline & & $\mathrm{M} 1+\mathrm{M} 2+\mathrm{M} 3$ & - & 100 & 90.0 \\
\hline
\end{tabular}

1920x1080 resolutions. There are three ways to change the aspect ratio from 16:9 to 4:3, scaling (M1), adding a black part at the bottom and the top (M2), and cropping left and right (M3). For Test 1 and Test 2, the robustness against resolution change has been measured by the extraction rates. For Test 3 , the resolution change and the aspect ratio change denoted M1 have been applied and the extraction rate is obtained.

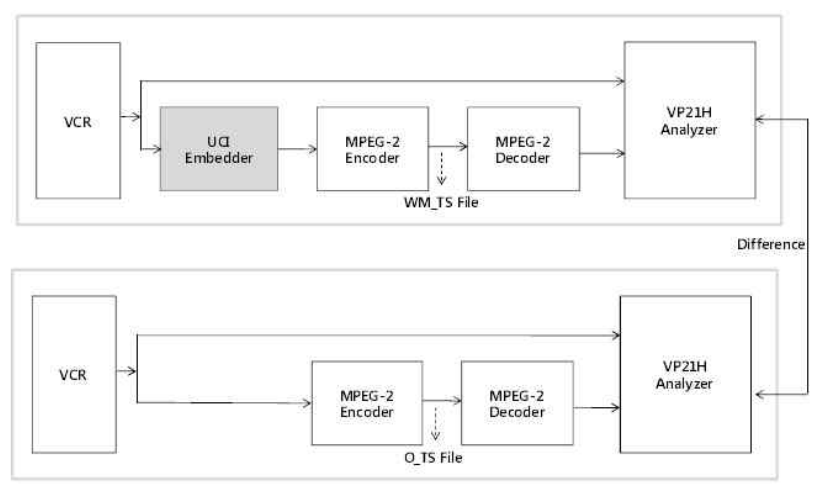

그림 6. DSCQS 화질 측정 구성도

Fig. 6. Video quality comparison using DSCQS.

We have measured the video quality using DSCQS (Double Stimulus Continuous Quality Scale). DSCQS is a subjective video quality measure defined in ITU-R Recommendation BT.500-7 [16]. We have used a commercial DSCQS measurement device called VP21H, which 100 scaled DSCQS can be obtained. The test scenario is illus-

표 4. 원본 대비 워터마크 삽입 영상 화질 측정(DSCQS) 결과

Table 4. The video quality comparison between the watermarked and the original in DSCQS

\begin{tabular}{|c|c|c|c|}
\hline \multirow{2}{*}{ Content \# } & \multicolumn{3}{|c|}{ DSCQS } \\
\cline { 2 - 4 } & WM_TS & O_TS & Difference \\
\hline 1 & 5.75 & 3.91 & -2.84 \\
\hline 2 & 7.416 & 6.08 & -1.38 \\
\hline 3 & 12.09 & 11.01 & -1.08 \\
\hline 4 & 10.16 & 8.15 & -2.01 \\
\hline 5 & 9.58 & 7.48 & -2.10 \\
\hline
\end{tabular}


trated in Fig. 6. For comparison of video quality between the watermarked and the original, we compare the decoded videos from the watermarked Mpeg-2 encoded file denoted as WM_TS and the no watermarked Mpeg-2 encoded file denoted as O_TS. The measured DSCQS and the difference are shown in Table 4 and the differences are very small.

\section{Conclusion}

UCI is a standard that assigns a unique identifier to digital resource and manages the resources more efficiently. This paper introduces the conceptual background of UCI and its advantages especially when it applied to broadcast contents distribution services, and presents a UCI embedder that is designed to embed UCI for the purpose of broadcast content distribution. Many watermarking systems have been proposed, however, the proposed watermarking system is designed to embed 28 byte UCI to make the embedded UCI robust in the modified version of broadcast content. In the proposed watermarking system, a watermark is generated based on UCI. The length of watermark payload is very important because the payload, image fidelity, and robustness are all trade-off in performance. We introduce our method that is carefully designed to generate a watermark against a downscaling attack. We design a watermark in a way that the maximum payload is 28 bytes and the watermark remains when the full HD broadcast contents in the size of $1920 \times 1080$ has changed into in the size of small resolution video. More challengeable part in designing a watermarking system to be used in the broadcast system is that to guarantee the good image fidelity and real-time embedding. As the high definition TV is popular, the required visual quality is very high and required performance to embed a watermark is high. The results have shown that our embedding does not distort the original significantly and the UCI embedded by our watermarking system is detected from the various modified version of content. To our knowledge, the introduced system is the first system that allows 28 byte UCI embedding in real-time in HD broadcast contents while providing the good quality and strong robustness.

\section{References}

[1] T. A. Z. Van Schyndel, R G and C. F. Osborne, "A digital watermark," in Proceedings of IEEE International Conference on Image Processing, vol. 2, November 1994, pp. 86-90.

[2] R. Wolfgang and E. Delp, "A watermark for digital images," in Proceedings of IEEE International Conference on Image Processing, vol. 3, September 1996, pp. 219-222.

[3] P. W. Wong and N. Memon, "Secret and public key image watermarking schemes for image authentication and ownership verification," IEEE Transactions on Image Processing, vol. 10, no. 10, October 2001, pp. 1593-1601.

[4] M. M.Yeung and F. Mintzer, "An invisible watermarking technique for image verification," in Proceedings of IEEE International Conference on Image Processing, vol. 2, October 1997, pp. 680-683.

[5] J. Fridrich, M. G. and Arnold C.Baldoza, "New fragile authentication watermark for images," in Proceedings of IEEE International Conference on Image Processing, September 2000, pp. 446-449.

[6] M. Wu and B. Liu, "Watermarking for image authentication," in Proceedings of IEEE International Conference on Image Processing, vol. 2, October 1998, pp. 437-441.

[7] D. Kundur and D. Hatzinakos, "Towards a telltale watermarking technique for tamper-proofing," in Proceedings of IEEE International Conference on Image Processing, vol. 2, October 1998, pp. 409-413.

[8] Liehua Xie and G.R. Arce, "Joint wavelet compression and authentication watermarking," in Proceedings of IEEE International Conference on Image Processing, vol. 2, October 1998, pp. 427-431.

[9] TTA KICS.OT-10.0058, "Universal Content Identifier (Standard on Digital Content Identification: Universal Content Identifier)," December 2008 .

[10] IETF RFC4179, S Kang, "Using Universal Content Identifier (UCI) as Uniform Resource Names (URN),” http://www.ietf.org/rfc/rfc4179. txt?number=4179), September 2005.

[11] Yoonsik Uhm, Zion Hwang, Minsoo Lee, Jaehoon Nah, Hwangjun Song, and Sehyun Park, "Content Protective Multi-Agent Platform for MsMu Service and Pattern-Based Content Management," ETRI Journal, vol. 32, no. 5, October 2010, pp. 665-675.

[12] I. J. Cox, J. Kilian, T. Leighton and T. Shamoon, "Secure Spread Spectrum Watermarking for Multimedia", IEEE Transactions on Image Processing, vol. 6, no. 12, 1997, pp. 1673-1687.

[13] Conting service, http://www.conting.co.kr. 
[14] M. Kutter, "Watermarking resisting to translation, rotation and scaling", in Proceedings of SPIE: Multimedia systems and applications, vol. 3528, Boston, USA, November, 1998, pp. 423-431.
[15] DeckLink, http://www.blackmagic-design.com/products/decklinkhdextreme.

[16] ITU-R Recommendation BT.500-7: Methodology for the subjective assessment of the quality of television pictures.

저 자 소 개

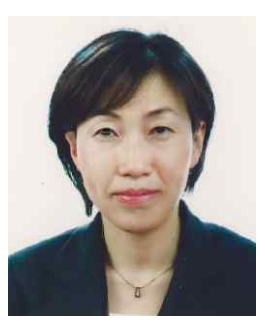

\section{김 연 희}

- 2000년 2월 : 아주대학교 정보및컴퓨터공학과 졸업 (공학사)

- 2002년 2월 : 아주대학교 정보및컴퓨터공학과 졸업 (공학석사)

- 2009년 1월 : George Mason University, Computer Science 졸업 (이학박사)

- 2009년 4월 현재 : 한국전자통신연구원(ETRI) 방통융합미디어연구부 선임연구원

- 주관심분야 : 영상 기반 정보은닉, 콘텐츠 보회유통, 영상신호처리 및 영상압축

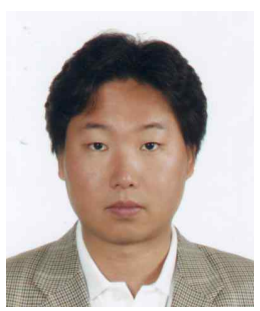

\section{김 현 태}

- 1999년 : 동국대학교 전자공학과 (공학사)

- 2001년 : 동국대학교 전자공학과 (공학석사)

- 2001년 2007년 : (주) 실트로닉 선임연구원

- 2007년 현재 : (주) 씨케이앤비 수석연구원

- 주관심분야 : 디지털 워터마킹, 이미지 프로세싱

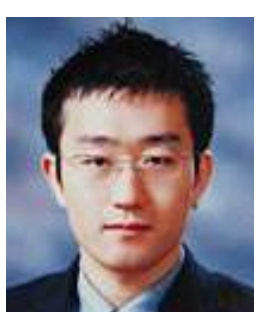

\section{이 주 영}

- 2003년 : 아주대학교 미디어학과 (학사)

- 2006년 : 한국과학기술원 전산학과 (석사)

- 2006년 현재 : 한국전자통신연구원 방통융합미디어연구부

- 주관심분야 : 콘텐츠 저작권 보호기술, 멀티미디어 데이터베이스 검색기술, 모바일 3DTV 기술

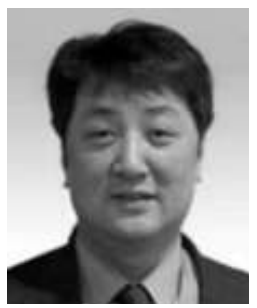

\section{남 제 호}

- 1992년 2월 : 홍익대학교 전기제어공학과 학사

- 1996년 12월 : University of Minnesota, Electrical Engineering 석사

- 2000년 12월 : University of Minnesota, Electrical Engineering 박사

- 2001년 2월 현재 : 한국전자통신연구원(ETRI) 방통융합미디어연구부 책임연구원

- 2007년 1월 현재 : 과학기술연합대학원대학교(UST) 이동통신 및 디지털방송공학과 부교수

- 주관심분야 : 멀티미디어 신호처리, 디지털 홀로그래피, 콘텐츠 보회/유통, 디지털방송기술, MPEG 